\title{
SENTIDOS E SIGNIFICADOS PARA O EXERCÍCIO DA VOCAÇÃO CIENTÍFICA
}

\begin{abstract}
produção do conhecimento científico tem se apresentado diante Ade um dilema, um dilema cada vez mais complexo, ao que parece. É como se cientistas vivessem sob o risco de uma morte por excesso. Afinal, avalanches de informação também podem induzir à ignorância. Seria o cúmulo do paradoxo em última instância: a morte do conhecimento pelo excesso de conhecimento.

De maneira menos metafórica, o fenômeno refere-se à tendência de proliferação de artigos, fato que não é exclusividade de nenhum país em particular, tampouco de uma área do conhecimento em especial. Tal como o próprio mundo contemporâneo, trata-se de um fenômeno global - embora, como a própria globalização, afete diferentes campos do conhecimento e regiões ou países de maneira desproporcional.
\end{abstract}

Estimativas menos sensacionalistas falam de 7.000 artigos científicos publicados diariamente. De todo modo, o volume da amostra é sempre tão grande que qualquer estudo ou avaliação mais precisa estaria comprometida. Ainda assim, parece razoável supor que parcela significativa desse número conteria erros estatísticos crassos. A relevância científica da maioria desses estudos, igualmente, seria, no máximo, relativa, para não dizer limitadíssima e muitos não serão consultados uma única vez sequer.

No Brasil, as políticas científicas têm influenciado decisivamente o rumo dos acontecimentos, que, como todo dilema, está clivado de tensões e ambiguidades, encerrando vantagens e desvantagens. De um lado, o efetivo aumento na disponibilidade e no acesso ao conhecimento, resultado da expansão do ensino superior, do aumento das bolsas de estudo, do estímulo à pós-graduação e ao financiamento à pesquisa, bem como o aprimoramento dos sistemas de avaliação universitária. De outro lado, o risco da banalização do conhecimento, em artigos que já vêm à luz sob o signo da condenação ao esquecimento, destituídos de valor e de sentido às vezes aos seus próprios autores, a quem a iniciativa representa tão somente mais um número em uma longa lista de pseudoproezas intelectuais - lista cada vez mais longa, mas também cada vez mais estéril.

Rigorosa vigilância epistemológica coloca-se como condição para 
evitar o embrutecimento. Nesse sentido, o processo editorial cumpre um papel potencialmente significativo, pois a possibilidade de publicação é submetida a filtros constituidores da própria dinâmica de avaliação por pares, sistemática adotada pela quase totalidade dos periódicos, como é o caso da Pensar a Prática. Atualmente, este processo parece constituir-se como um dos poucos momentos em que pesquisa e pesquisadores podem se submeter, de fato, à crítica da comunidade de pesquisadores ligados à sua temática de estudo. Não é outro o motivo pelo qual um dos nossos desafios tem sido, justamente, o de tentar aprofundar a capacidade do processo editorial em si mesmo, de fomentar e instituir debates, garantindo que a dinâmica de avaliação de artigos, ademais, sempre espremida pela corrida contra o relógio, não se reduza a um procedimento autômato e meramente burocrático.

Mais que nunca, o processo editorial deve constituir-se como uma arena de debates entre especialistas, lugar em que autores, avaliadores e editores terão a oportunidade de dialogar, de criticar e ser criticado, de ensinar e de aprender, de convencer e ser convencido. Radicalizar, pois, o fluxo de comunicação entre autores e avaliadores, generalizando, enfim, uma postura crítica e de fomento ao debate, parece-nos, nesse momento, uma palavra de ordem deveras interessante.

A fim de dar prosseguimento à contínua busca de aprimoramento do processo editorial, além disso, este número da revista Pensar a Prática traz uma novidade: nova divisão de sumário, a qual agora inclui um item dedicado aos artigos de revisão (acrescido às já existentes seções de artigos originais, ensaios e resenhas). Três artigos inauguram a nova seção, dedicada, especificamente, a trabalhos que têm por objeto resumir, analisar, avaliar ou sintetizar trabalhos teóricos ou de investigação já publicados. Dois deles tratam de pedagogias dos esportes coletivos, enquanto outro aborda a temática das atividades circenses na Educação Física escolar. Na seção de artigos originais, dedicada à comunicação de resultados de pesquisa empírica com dados originais, um total de seis escritos: dois deles tematizando, respectivamente, os efeitos e as dificuldades de adesão às práticas de atividades físicas, além de estudos sobre os jogos indígenas, sobre a história de clubes esportivos de ascendecia alemã no interior do Rio Grande do Sul, as concepções teóricas subjacentes aos currículos de Educação Física em duas cidades do Paraná e a configuração de espaços de dança em Goiânia. Na seção dedicada aos ensaios, dois escritos sobre Educação Fí- 
sica escolar, acompanhados por uma reflexão sobre a dimensão estética do esporte por meio da imagem pública de dois atletas prestigiados internacionalmente.

Desejamos a todos boa leitura.

Ana Márcia Silva

Ari Lazzarotti Filho

Cleber Dias

Editores 